\section{'Inducer', a Tree Morning Glory Rootstock Cultivar for Use in Breeding Sweetpotatoes}

\section{P.D. Dukes', Alfred Jones ${ }^{2}$, and J.M. Schalk ${ }^{3}$ \\ U.S. Vegetable Laboratory, Agricultural Research Service, U.S. Department of Agriculture, Charleston, SC 29414}

Additional index words. sweetpotato, Ipomoea batatas, Ipomoea camea. ssp. fistulosa, disease resistance, insect resistance, vegetable breeding, graftage, flower and seed induction

'Inducer' 'rootstock [Ipomoea camea Jacq. ssp. fistulosa (Mart. ex. Choisy) D. Austin] was developed jointly and released in 1988 by the USDA and the South Carolina Agricultural Experiment Station, Edisto Research and Education Center, Clemson Univ., Blacksville, S.C. This rootstock is useful for stimulating induction and/or increased flowering and subsequent seed set of sweetpotato [Ipomoea batatas (L.) Lam.] scions in field breeding nurseries and in reproductive physiological research.

\section{Origin}

'Inducer', previously tested as IF-80-17, was selected in 1980 for its many unique characteristics needed for graftage studies, including early and prolific flowering, vigorous upright plant habit, resistance to fusarium wilt [Fusarium oxysporum f. sp. (Wr.) Snyd. \& Hans. batatas], and tolerance to rootknot nematodes (Meloidogyne spp.). This cultivar originated as an open-pollinated seedling from a large polycrossed population (Accession no. 66.26). The original source of our collection was F.W. Martin, USDA, ARS, Tropical Agricultural Research Station, Mayaguez, P.R.

\section{Description}

'Inducer' has a rapidly growing, upright, bushy habit reaching 3 to $4 \mathrm{~m}$ in height in one season at Charleston, S.C. (Fig. 1A). This rootstock must be propagated by stem cuttings, since it is not self-fertile under environmental conditions in the areas of the southern United States where it was tested, It will, however, produce abundant viable seed if allowed to polycross with other se-

Received for publication 15 May 1989. Appreciation is expressed to M.G. Hamilton for assistance with some phases of the evaluation. We acknowledge with thanks the dedication and technical assistance of E.L. Corley, Jr., J.C. Simmons, and B.W. Davis. The cost of publishing this paper was defrayed in part by the payment of page charges. Under postal regulations, this paper therefore must be hereby marked advertisement solely to indicate this fact.

'Research Plant Pathologist.

${ }^{2}$ Research Geneticist.
${ }^{3}$ Research Entomologist. lections from this population. Long stem cuttings $(25-40 \mathrm{~cm})$ will produce fibrous roots very quickly in a moist medium without hormone treatment. Flowering of rooted cuttings or scions of grafted sweetpotato is usually initiated within 60 days after trans- planting to a field nursery. Flowers of the rootstock are about twice the size of the sweetpotato flower and are borne abundantly in clusters. The large flower has a light lavender corolla and darker lavender throat. The grafted rootstock can be transplanted to the field along with other breeding clones of sweetpotato and treated in the breeding nursery in a similar manner. Compatibility of graft unions has been excellent in all cases (Fig. 1B). In a few cases, scion growth was somewhat reduced compared to ungrafted vines, but seeds were produced. Seed production is quite variable, depending on the scion used, but generally some seeds are produced on all sweetpotatoes of all types, if managed properly. (Fig. 1C).

\section{Disease and insect resistance}

'Inducer' has a high level of resistance to stem rot (wilt) (caused by the soil-borne fungus Fusarium oxysporum f. sp. batatas ) and

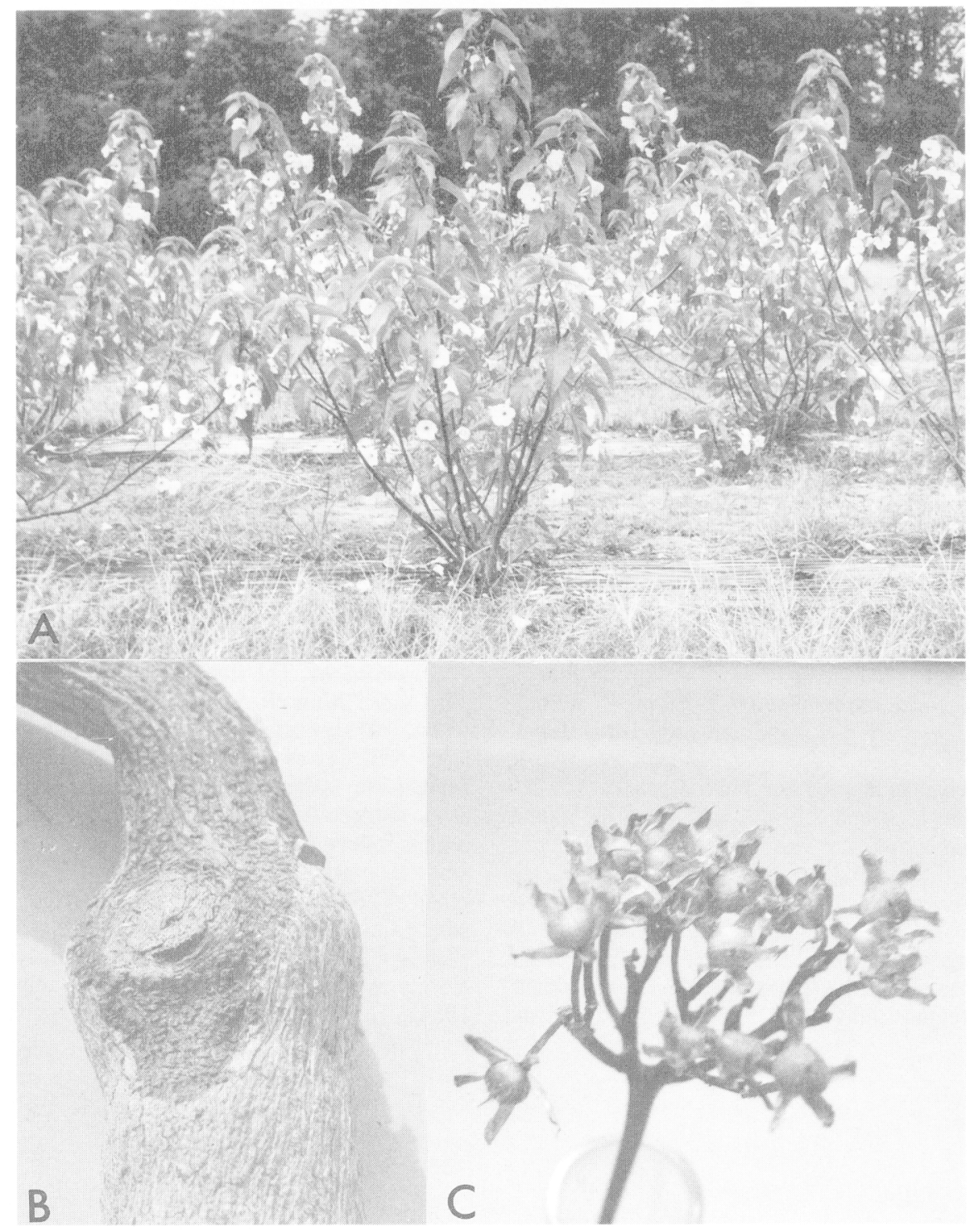

Fig. 1. (A) Vigorous flowering plant of 'Inducer' showing upright habit. This plant is $2.5 \mathrm{~m}$ high and grew from a $45-\mathrm{cm}$ cutting in 4 months. (B) An excellent graft union. Upper darker bark is the sweetpotato scion, lower lighter bark is 'Inducer' rootstock. (C) An unusually large seedhead produced by 'Jasper' (L9-190) scion with 'Inducer' as the rootstock. 
tolerance to root-knot nematodes (Meloidogyne spp.). None of the foliage-, stem-, or root-infecting pathogens that commonly cause diseases of sweetpotato have been observed on 'Inducer', except that the root system is susceptible to scurf (Monilochaetes infuscans Ell. \& Halst. ex. Harter). Also, 'Inducer' has been observed for the past 5 years to be remarkably free of all insect pests that commonly damage sweetpotato roots and foliage. The plants, once established in field nurseries, are very drought-tolerant. However, as with sweetpotato, 'Inducer' is very sensitive to cold ( < 13C) and frost, especially the foliage; generally the root 'system will not survive at the test location without some protection during the winter.

\section{P e r f o r m a n c e}

Considerable research on inducing sweetpotato plants to flower and set seed for breeding has been done during the past 70 years in the United States, Japan, Argentina, New Guinea, and other countries (Folquer, 1961; Kehr et al., 1953; Kokayashi and Nakanishi, 1979; Lam and Cordner, 1955; Lardizabal and Thompson, 1988; Miller, 1937; Mikell et al., 1948; van Rheenen, 1965). In 1978 and 1979, lpomoea nil, seven accessions of $I$. carnea ssp. fistulosa, some selections of $I$. batatas that flower profusely, and other species were evaluated in greenhouse and field studies in search of a suitable and efficient rootstock for use in our large polycross field nurseries of selected parental plants. Native insects pollinated all the entries in each nursery. Based on these trials, selections of I. carnea ssp. fistulosa were chosen for further testing because of their 1) vigorous, upright growth with thick multistem-habit, making grafting easier and quicker; 2) early profuse flowering that continued through the growing season; and 3) large vigorous root systems that anchored and supported the grafted scions in the early stages of growth.

'Inducer', a selection from Accession no. 66.26 , has been tested for its ability to induce flowering and seed set in numerous comparative research studies involving other rootstock, chemical treatments, management of rootstock, and girdling of plants in field nurseries. A preliminary report dealing with some aspects of the I. carnea ssp. fistulosa population, from which 'Inducer' was selected, has been presented (Dukes and Jones, 1981). 'Inducer' consistently induced more seed production on scions of various different sweetpotato selections and plant introductions (Fig. 1C) than any other treatment or rootstock. It produced, on the average, $50.4 \%$ more seed per grafted plant than any other selected or unselected rootstock to which it was compared. Seeds produced on the scions of 'Inducer' were larger, had better viability, and produced more vigorous seedlings than our other improved $I$. carnea ssp. fistulosa selections. This rootstock has been used extensively for flower induction to facilitate the transfer of desirable traits in nonflowering sweetpotato breeding clones and in genetic investigations, - including the transfer of the soil rot (pox) disease [Stretomyces ipomoea (Person \& W.J. Martin) Waksman \& Henrici] resistance from a plant introduction to improved types (Dukes and Jones, 1981; Jones et al., 1987; Lardizabal and Thompson, 1988). 'Inducer' has performed well in breeding, programs at Charleston, and we believe it would benefit sweetpotato breeding research in other regions of the United States and the world.

\section{Availability}

A limited quantity of stem cuttings will be available for pro rata distribution to bona fide sweetpotato breeders and research personnel upon written request to P. D. D., U.S. Vegetable Laboratory, 2875 Savannah Highway, Charleston, SC 29414. The USDA, ARS Regional Plant Introduction Station, Sweetpotato Repository, 1109 Experiment St., Griffin, GA 30223-1797, also has this cultivar in its collection.

\section{Literature Cited}

Dukes, P.D. and A. Jones. 1981. The influence and evaluation of rootstock of Ipomoea carnea ssp. fistulosa on inducing flowering and seed development of sweet potato scions. HortScience 16(3):288. (Abstr.)

Folquer, F. 1961. Induccion de floración y fructficación en batatas mediante injerto sombre Ipomoea fistulosa. Univ. Nat. Tucumán Publ. 841.

Jones, A., P.D. Dukes, J.M. Schalk, M.G. Hamilton, and R.A. Baumgardner. 1987. 'Southern Delite' sweet potato. HortScience 11(1):329330.

Kehr, A. E., Y.C. Ting, and J.C. Miller. 1953. Induction of flowering in the Jersey type sweet potato. Proc. Amer. Soc. Hort. Sci. 62:437440.

Kokayashi, M. and T. Nakanishi. 1979. Flower induction by top-grafting in sweet potato. In: Sweet potato. Proc. Fifth Intl. Symp. Trop. Root and Tuber Crops. Philippine Council of Agr. and Resources Res. and Dev.. Manila. p. 4958

Lam, S. and H.B. Cordner. 1955. Flowering hormone in relation to blooming in sweet potato. Science 112:140-141.

Lardizabal. R.D. and P.G. Thompson. 1988. Hydroponic culture, grafting and growth regulators to increase flowering in sweet potato. HortScience 23(6):993-995.

Miller, J.C. 1937. Inducing the sweet potato to bloom and set seed. J. Hered. 28:347-349.

Mikell, J. J., J.C. Miller, and J.B. Edmond. 1948. Flowering of the Jersey type sweet potatoes. Science 107:628.

van Rheenen, H.A. 1965. Flowering stimulation in sweet potato. Euphytica 14:271-275. 